\title{
Consumer Loyalty as a Factor of Establishing the Competitive Advantages in a Company under the Market Conditions
}

\author{
Alina V. Chesnokova ${ }^{1}$, Oksana I. Radina ${ }^{1} \&$ Regina I. Serdyuk ${ }^{1}$ \\ ${ }^{1}$ Don State Technical University, Shakhty, Russia \\ Correspondence: Alina V. Chesnokova, Don State Technical University, Anadyrskiy proezd st., 47-2, ap. 34, \\ 129346, Moscow, Russia. Tel: 8-910-433-50-12. E-mail: 4335012@gmail.com
}

Received: September 2, 2014

doi:10.5539/ass.v10n23p255
Accepted: September 25, 2014 Online Published: November 25, 2014

URL: http://dx.doi.org/10.5539/ass.v10n23p255

\begin{abstract}
The objective of the work is the theoretical rationale for the ratio of the customer loyalty to a number of the major factors of establishing the competitive advantages of a company and developing the practical guidelines for managing the consumer loyalty. As a result of the study it has been found, that the consumer loyalty determines their commitment to the company and its products, which is developed while building the relationships between the company and its consumers through the relationship marketing. There are four major factors of establishing the competitive advantages of a company under the market conditions: product quality, service quality, product price and consumer loyalty. In this study the following guidelines are suggested to companies in order to ensure consumer loyalty: impress the consumers, ensure consistently high quality of goods and services, earn confidence of the consumers, hear the consumers' criticism, build your own distribution network and surprise them with understanding. While managing the consumer loyalty companies not only draw new consumers, entice consumers away from the rival companies, but also retain its customers. While retaining the consumers companies get a double advantage, as: the process of retaining consumers is less complicated and costly, than the process of drawing and particularly enticing the consumers away from the competitors; the consumers, who are loyal to the company for a long period of time, regularly buy its products, ensuring the stability of its sales, profit and profitability.
\end{abstract}

Keywords: consumer loyalty, competitive advantage, market conditions, relationship marketing

\section{Introduction}

Global competition contributes to transforming the conditions of companies operations, making it more and more dependent on the consumers' requirements (Popkova et al., 2013a). The growth of the production capacity eliminates the production problem and exacerbates the issue of distributing the finished products (Elsherpieny et al., 2014; Uncles, 1994). Under the current market conditions producing the goods, which meet the customers' requirements is not sufficient for companies - it is also necessary to build relationships with customers in order to ensure their loyalty (Yusof et al., 2014).

Not only the manufactured product, but the whole company should meet the requirements of consumers (Cole Ehmke, 2013; Sharp \& Sharp, 1997). The consumers' power has increased, so there is a bitter fight for every consumer among the companies. It is necessary to ensure consumer loyalty to one's own company and manufactured products in order to retain one's customers and entice the product consumers away from the competitors what will establish the sustainable competitive advantages of the company (Etuk et al., 2014; Aweng $\&$ Fatt, 2014). Hence, the relationship marketing intended to managing consumer loyalty and ensuring the company's competitiveness becomes more popular.

\section{Study Data and Methods}

Such scientific research methods as the method of the system analysis, the content analysis of the scientific literature, the economic and statistical, comparative, structural and logical analysis, graphical methods of representing information and the formalization method have been used in the article.

The theoretical and methodological essentials of the study have been the fundamental work on marketing by M. Porter. The work also includes the research data of the theoretical and methodological nature, related to the study 
of operating the Russian service market by the modern Russian authors Baburina V. A., Gorbashko E. A., Oruch T. A. and Razomasova E. A..

While measuring the consumers' commitment in the article the following methods have been used:

The method of "sharing the needs", according to which the degree of consumer loyalty is defined in terms of numbers. Brand loyalty could be determined, according to how often and in what ratio this brand is bought relating to other brands. Many marketers suppose that if the share of the repeat purchases is $67 \%$, then such consumer is definitely loyal. The consumers, the rate of whose repeat purchases is less than $67 \%$, belong to the "defectors". A problem relating to this method is that consumers do not always buy a particular brand, as they are actually loyal to it (we have already mentioned the differences between the behavioral loyalty and the loyalty associated with the attitude, i.e. commitment).

"The Traditional Approach". Its basis is determine "the intent to purchase" any given brand before making a purchase. If the buyer's intention is defined as the "high" one, then it is taken for a statement that the consumer could be loyal or committed to the brand. Thus, the consumer could have no real choice. Therefore, this approach to measuring the degree of commitment could distort the real picture of life.

A conversion model, which allows measuring a degree / a rate of the commitment. In the model four basic indexes are used (McBride \& Sansbury, 2011):

- Brand Satisfaction. The higher the degree of such satisfaction, the higher the probability of its transformation into commitment. However, satisfaction is uncorrelated with behaviour, and therefore understanding the nature of satisfaction does not fully reveal the reasons for any consumers' actions. Nevertheless, satisfaction is a crucial component in understanding the relationships between a consumer and a brand.

- Alternatives. One of the reasons for which consumers do not change their brand to another, is as follows: they understand, that the alternatives are just as bad as the brand which they acquire, or are even worse. The brand is not measured independently from the competing brands. It should be also borne in mind, that a high degree of satisfaction does not necessarily mean that the relationships with the customer are unwavering: If a consumer looks at a competing brand through rose-coloured glasses, it could result in moving away from this brand.

- The Importance of Selecting a Brand. If selecting a brand is of no importance for the consumer, it will be difficult to achieve his commitment. Selecting a brand, as well as a product category, should somehow be interesting to the consumer. Only in this case it is possible to talk about the presence of the commitment. The more valuable is selecting a brand for the consumer, the more likely he will spend time trying to make a final decision on which brand to select. In case of dissatisfaction with the acquired brand the committed consumer will be more tolerant towards it. (One could draw an analogy between this and the marriage, where firstly the couple takes steps to find a solution acceptable for both in case of a conflict, instead of the immediate separation.) Therefore, it may be concluded, that the higher the rate of the commitment is, the higher the level of tolerance/allowance of the brand is in case of dissatisfaction with it.

- Degree of Uncertainty or Ambivalence. This index is a key one in the commitment model. The more uncertain about selecting any given brand the consumer is, the more likely he will postpone the final decision on the purchase until the last moment. Therefore, such consumers need an incentive which they receive directly in the store, as it is where the final choice takes place.

\section{Results}

The objective of the competitive strategy of a modern company is achieving the sustainable competitive advantage and thus, ensuring the stable competitiveness and efficiency of business for a long term. One of the main objectives of the marketing policy is increasing the long-term financial performance of the company.

A company uses some resources, which should meet the following requirements in order to achieve the competitive advantages:

1. resources should be valuable;

2. resources should be rare among the competitors;

3. it should be difficult to imitate the resources;

4. There should be no strategically equivalent substitutes for these resources.

The competitive advantages could be provided through a unique combination of the resources used by the company: by differentiating the finished product and / or it's low cost (Taylor, 2014). The sustainability of the competitive advantages results in increasing the market share and improving the financial performance indexes 
of the company for the long term. The development and implementation of the competitive marketing policy includes also the recognition of the ties between the elements of the marketing complex, as well as assessing the impact of the competitive market conditions on the marketing complex.

There is a relationship between the level of the product quality, the costs for its promotion and the price of it, which affects the development of the company's marketing. The competitive advantage is implemented subject to three factors (Tierney, 2014):

1. the company's marketing policy;

2. the company's features and its turning into advantages;

3. the sectorial features and its beneficial use by the company.

An important aspect of the marketing policy of a company is the relationships: relationships with clients, contractors and competitors. The competitive advantage is achieved, when the company acquires the attributes, which allow it to operate at a higher level than other companies of the same field. In this work, the following key aspects relating to the company's competitive advantages are separated:

- Companies could achieve the competitive advantage through the implementation of the value delivery strategy. These strategies should be rare, valuable, and uninterchangeable.

- The competitive advantages are stable if the competitors could not quickly and easily imitate and use for their own company, and thus, the uniqueness could be ensured for a long period of time.

- Developing the sustainable competitive advantage requires consumer loyalty, their sympathy, manufacturing unique products, using the distribution channels conforming to the goods features, building the relationships with suppliers, developing the reputation and high-quality service.

The company's competitive advantage reflects its superiority over the competitors within this field. Achieving the competitive advantages solidifies the company's positions and ensures its competitiveness. The sustainable competitive advantage occurs when a company acquires or develops an attribute or a combination of attributes which allow it to outperform its competitors.

These attributes could cover the access to natural resources or the access to skilled human resources. The competitive advantage is a key factor, which determines high performance and ensures the survival and advantageous position of a company in the market.

In this study, the following factors of the company's competitive advantages are separated:

1. Manufacturing the products which fill the consumers' needs more, than the competitive products (product quality)

2. Customer service in a more qualitative way, than the competitors' one (service quality).

3. Building the business processes so, as to manufacture the products at lower costs than the competitors and sell it at a lower price (a product price).

4. Building relationships with customers so, that they are inclined to buy the products of this company (consumer loyalty).

Thus, consumer loyalty is a factor of establishing the competitive advantages of a company under the market conditions, which are provided through the following key aspects (Dowling \& Uncles, 1997):

1. Distribution. Sales of the company's products should be relevant to the consumers' needs and a required image of the company. The location is also a crucial factor in selecting a products supply company. The company's location should meet the peculiarities of its business and be a part of its image, brand.

2. Selling Unique Products. Building the stable relationships with suppliers could provide the company with the exclusive rights to sell the goods in a certain region and to obtain the popular resources which are in short supply.

3. Customer Service. The service quality to a large extent determines the consumers' attitude to the company and their perception of its products. Companies constantly solve the optimization problems by finding the balance between the price and service quality.

4. Loyalty Programs. Consumers should be committed to purchasing the goods and services of a certain company. This could be achieved by branding, positioning and carrying out the loyalty programs. The loyalty program involves retaining customers through providing them with the favourable conditions of service in the company and issuing the so-called loyalty cards. If a consumer uses a loyalty card when making purchases, the company could track all of its transactions with the customer and store the data on him in its data storage, which tracks the customer's needs.

5. Social Responsibility. The moral aspect of business - is the face of a modern company. It is much easier to achieve consumer loyalty and to gain the public recognition for the socially conscious company. 
In this study the following guidelines are suggested to companies in order to ensure consumer loyalty:

- Impress customers, provide them with a fantastic product or render an extraordinary service - as a result you could rely on their confidence for a long time;

- Ensure consistently high quality of goods and services (a service), and they will tell their friends and colleagues about your company, and develop its reputation;

- Earn confidence of the consumers, initiate a dialogue with them, and they will say what do they exactly want to see in the market, what needs do they have, while targeting the company towards implementing the innovations, which are in demand and ensure high profitability of the company;

- Hear the consumers' criticism, and they will tell you where does the company make a mistake and give it time to correct its errors;

- Build your own distribution network, which will serve as an extension of your sales, when the sales will decrease, in order to ensure stable sales of the products;

- Surprise them with understanding, speed and availability, and they will treat you as a true friend.

While managing the consumer loyalty companies not only draw new consumers, entice consumers away from the rival companies, but also retain its customers. While retaining the consumers companies get a double advantage, as:

1. the process of retaining consumers is less complicated and costly, than the process of drawing and particularly enticing the consumers away from the competitors;

2. the consumers, who are loyal to the company for a long period of time, regularly buy its products, ensuring the stability of its sales, profit and profitability.

\section{Discussion}

Under the current market conditions the competitive marketing policy involves the implementation of the relationship marketing as one of the key functional tools for improving the business performance (Aweng \& Fatt, 2014; Kanagal, 2013; O'Brien \& Jones, 1995). The relationship marketing allows identifying, establishing, maintaining, enhancing, modifying, and terminating the relationships with customers in order to make a value to the consumers and to ensure the company's profitability in the current period and in the long term (Hammadi et al., 2014).

Managing the relationships with consumers allows building partnership and trust relationships with them, interact with customers not only at physical, but also psychoemotional level (Popkova \& Tinyakova, 2013a; Popkova \& Tinyakova, 2013). The relationship marketing allows managing the relationships with customers and involves the system approach based on the following fundamental provisions (Popkova et al., 2013b):

1. the relationships are mutually taken and recognized by both parties: the companies and consumers;

2. the relationships go beyond the unintentional contacts and have a special status.

These relationships should have the following characteristics in order, that consumers are interested in building the relationships with the same products supply company and acquiring its products: variability, complexity and involvement. The relationship marketing is carried out at three levels (Beuder, 2013) (рис. 1).

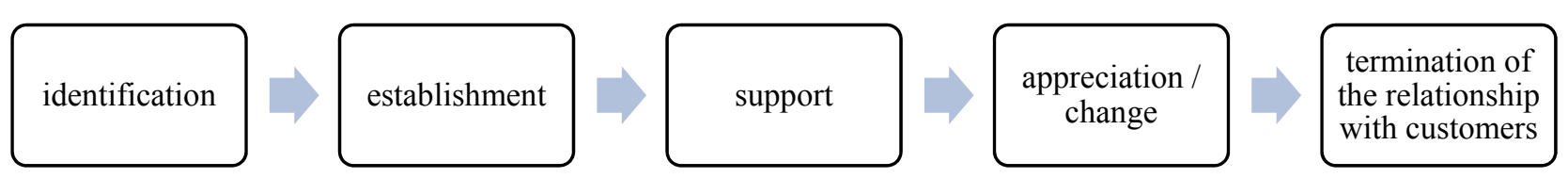

Figure 1. Levels of consumer loyalty management through relationship marketing

As we can see from the figure 1 , the first level of the relationship marketing relies primarily on the price incentives for ensuring consumer loyalty (Dowling \& Uncles, 1997). However, the stability of the competitive advantage is minimum at this level (Hassan, 2014). The second level of the relationship marketing relies primarily on the social networks, although the price remains an essential element. It includes personalization and building the relationships (Hammadi et al., 2014). The third level of the relationship marketing is based on the structural solutions of the consumers' problems.

According to the stated above, in this study the process of managing the consumer loyalty is implemented using the relationship marketing and involves the identification, establishment, maintenance, enhancement, 
modification and termination of the relationships with customers in order to make a value to them and to provide the company with the profit in the current and future periods during the relational exchange (figure 2).

Growth of sustainable

competitive advantage

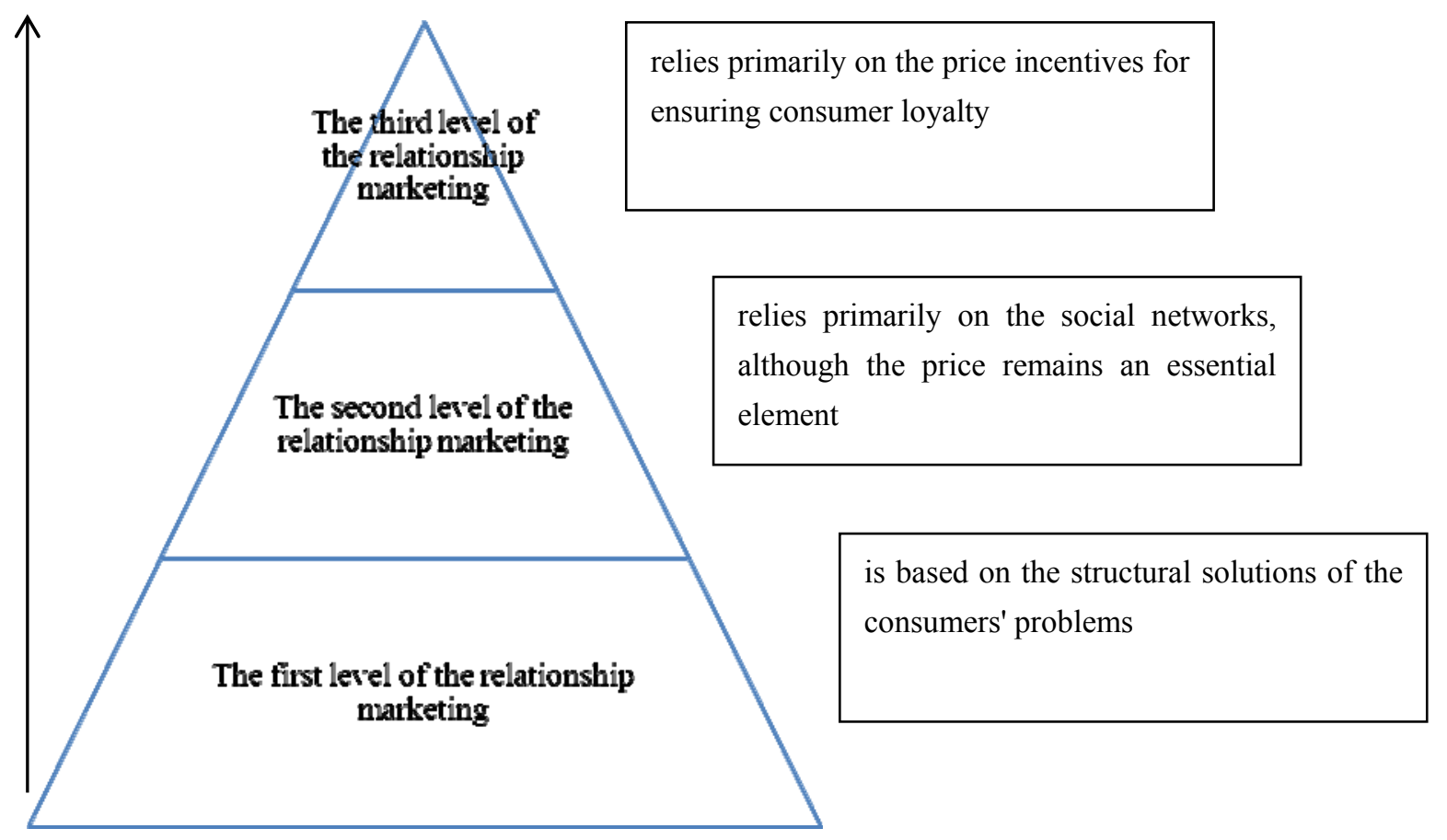

Figure 2. The process of customer loyalty of management implemented by means of relationship marketing

\section{Conclusion}

Thus, it may be concluded, that the consumer loyalty determines their commitment to the company and its products, which is developed while building the relationships between the company and its consumers through the relationship marketing. Four major factors of establishing the competitive advantages of a company under the market conditions could be drawn up: product quality, service quality, product price and consumer loyalty, which acts as a key factor increasing the importance of other factors and ensuring the stability of the company's competitive advantages.

Companies should establish the optimal distribution, customer service, sell unique products, carry out loyalty programs and be socially conscious in order to ensure consumer loyalty. It is also necessary to establish the consumer feedback in order to know their opinion of the company and competitors, to hear their offers and suggestions, as well as the criticism of the company, to anticipate their needs and fill it before the competitors will be able to do it. Hence, consumer loyalty is the main target of the company's operations and a factor of establishing the sustainable competitive advantages.

The restrictions of this work lie in the partial effect of the proposed guidelines for managing the consumer loyalty. Hence, the prospects for the further studies on managing consumer loyalty lie in the search of the innovative methods of managing the consumer loyalty and methods, ensuring the unconditional result.

As a result of the study revealed that in the Russian economic thought relationship marketing is a relatively new phenomenon, and it confirmed the study of literature by authors such as E. G. Popkova, S. S. Morkovina, E. V. Patsyuk, E. A. Panyavina and E. V. Popov. In foreign economic thought relationship marketing is an integral part of loyalty and competitive strategy, which is confirmed by studies Aweng, E. R. and C. C., Fatt, Dowling, G. R. and M. Uncles, Etuk, I. E., T O James and B. K. Asare and others. The contribution of this work in the theory and practice of formation of competitive advantages in the market conditions is the justification of the need to ensure the loyalty of consumers for the formation of stable and long-term competitive advantages. 


\section{References}

Aweng, E. R., \& Fatt, C. C. (2014). Survey of Potential Health Risk of Rubbish Collectors from the Garbage Dump Sites in Kelantan, Malaysia. Asian journal of applied sciences, 1, 5-11.

Beuder, J. (2013). Four Core Principles of Retail Customer Loyalty and Retention. Corner expert, 8, 5-9.

Cole Ehmke, M. S. (2013). Strategies for Competitive Advantage. Western Extension Marketing Committee, 8, 51-58.

Consumer Loyalty Programs. (2011). Hanover Research: Sales and Marketing Practice, 7, 3-27.

Creating Customer Loyalty: A Customer-Centric Approach. (2008). Accenture, 8, 5-11.

Dowling, G. R., \& Uncles, M. (1997). Do Customer Loyalty Programs Really Work? Sloan Management Review, $38,71-82$.

Elsherpieny, E. A., Hassan, A. S., \& El Haroun, N. M. (2014). Application of Generalized Probability Weighted Moments for Skew Normal Distribution. Asian journal of applied sciences, 1, 14-18.

Etuk, I. E., James, T. O., \& Asare, B. K. (2014). Fractional Cointegration Analysis of Fisher Hypothesis in Nigeria. Asian Journal of Applied Sciences, 1, 30-33.

Hammadi, K. J., Al-Molla, A. K. J., \& Al-Maadhdei, M. E. (2014). Genetic Relatedness among Iraqi, Jordanian and Iranian TYLCV Based on the Identity Analysis. Asian Journal of Applied Sciences, 1, 19-22.

Hassan, S. M. (2014). Electromagnetic Therapy Control the Effect of Bacteria on Liver Tissue: Histopathological, Histochemical and Immunohistochemical Studies. Asian Journal of Applied Sciences, 1, 23-25.

Kanagal, N. (2013). Role of relationship marketing in competitive marketing strategy. Journal of Management and Marketing Research, 3, 5-17.

McBride, J., \& Sansbury, T. (2011). \$48 billion worth of consumer loyalty reward points dispensed each year, yet one-third are never cashed in. Retrieved from http://www.colloquy.com/press_release_view.asp? $\mathrm{xd}=95$

O'Brien, L., \& Jones, C. (1995). Do Rewards Really Create Loyalty? Harvard Business Review, 5, 75-82.

Popkova, E. G., \& Tinyakova, V. I. (2013). Drivers and Contradictions of Formation of New Quality of Economic Growth. Middle-East Journal of Scientific Research, 11, 1635-1640.

Popkova, E. G., \& Tinyakova, V. I. (2013). New Quality of Economic Growth at the Present Stage of Development of the World Economy. World Applied Sciences Journal, 5, 617-622.

Popkova, E. G., Morkovina, S. S., Patsyuk, E. V., Panyavina, E. A., \& Popov, E. V. (2013). Marketing Strategy of Overcoming of Lag in Development of Economic Systems. World Applied Sciences Journal, 5, 591-595.

Popkova, E. G., Shahovskaya, L. S., Romanova, M. K., \& Dubova, Y. I. (2013). Bases of Transition of the Territory to Sustainable Development: Modern City. World Applied Sciences Journal, 1, 1499-1507.

Sharp, B., \& Sharp, A. (1997). Loyalty Programs and Their Impact on Repeat-Purchase Loyalty Patterns. International Journal of Research in Marketing, 14, 473-486. http://dx.doi.org/10.1016/S0167-8116(97) 00022-0

Taylor, R. (2014). Analytics at the Core of Customer Engagement. Retrieved from http://www.loyaltylab.com/ blog/2013/09/analytics-at-the-core-of-customer-engagement-2/

Tierney, J. (2014). Customer Behavior Management at the Core of Loyalty Program Success. Epsilon \& Walgreens, 4, 12-18.

Uncles, M. (1994). Do You or Your Customers Need a Loyalty Scheme? Journal of Targeting, Measurement and Analysis for Marketing, 2, 335-350.

Yusof, Z. M., Misiran, M., \& Harun, N. H. (2014). Job Satisfaction among Employees in a Manufacturing Company in North Malaysia. Asian journal of applied sciences, 1, 26-29.

\section{Copyrights}

Copyright for this article is retained by the author(s), with first publication rights granted to the journal.

This is an open-access article distributed under the terms and conditions of the Creative Commons Attribution license (http://creativecommons.org/licenses/by/3.0/). 